\title{
DPP4 wt Allele
}

National Cancer Institute

\section{Source}

National Cancer Institute. DPP4 wt Allele. NCI Thesaurus. Code C91299.

Human DPP4 wild-type allele is located in the vicinity of 2 q24.3 and is approximately 82 $\mathrm{kb}$ in length. This allele, which encodes dipeptidyl peptidase 4 protein, plays a role in the mediation of proteolysis and the regulation of $\mathrm{T}$ cell activation. 